\title{
Induction of Human B Cell Antigens in Non-T
}

\section{Cell Acute Lymphoblastic Leukemia}

\author{
Lee M. Nadler, Jerome Ritz, Michael P. Bates, Edward K. Park, \\ Kenneth C. Anderson, Stephen E. Sallan, and Stuart F. Schlossman, \\ Division of Tumor Immunology, Sidney Farber Cancer Institute and \\ Department of Medicine, Harvard Medical School, \\ Boston, Massachusetts 02115
}

A B S T R A C T Leukemic cells from $70 \%$ of patients with Ia+CALLA+ non-T cell acute lymphoblastic leukemia (ALL) express an antigen (Bl) found on all normal B lymphocytes. In this study, ALL cells that do not express the Bl antigen were studied in an attempt to further elucidate the cellular lineage of these tumors. Non-T cell ALL lines and tumor cells isolated from patients with non-T cell ALL that are $\mathrm{Ia}+\mathrm{CALLA}+\mathrm{Bl}-$ were studied in vitro with a variety of agents known to promote cellular differentiation. Phorbol diester (TPA) or phytohemagglutinin conditioned leukocyte culture media were capable of inducing the expression of $\mathrm{Bl}$ on all four non-T cell ALL lines tested. In contrast, Bl could not be induced under the identical conditions on a promyelocytic leukemia line or a $\mathrm{T}$ cell lymphoblastic leukemia line. With the induction of $\mathrm{Bl}$ on non-T cell ALL lines, cytoplasmic $\mu$-heavy chain $(\mathbf{c} \mu)$ became undetectable, whereas the expression of CALLA and Ia were unchanged. The expression of $\mathrm{Bl}$ was accompanied by a decrease of cellular proliferation and DNA synthesis, but no significant morphologic changes were noted. In addition, no other B or $T$ cell antigens were detected.

The cellular origin of non-T cell ALL was further investigated using tumor cells isolated from leukemic patients. Tumor cells from eight patients with $\mathrm{Ia}+\mathrm{CALLA}+\mathrm{BI}-\mathrm{c} \mu-\mathrm{ALL}$ could be induced in vitro with TPA to express both $B l$ and $c \mu$. In contrast, cells from five patients with Ia +CALLA-BI-c $\mu-$ non-T cell ALL could not be induced with TPA to express CALLA, Bl, or $\mathrm{c} \mu$. These studies suggest that the non$T$ cell ALL are heterogeneous and represent a spectrum of early $B$ cell differentiation including the prepre-B cell $(\mathrm{Ia}+\mathrm{CALLA}+\mathrm{Bl}-\mathrm{c} \mu-)$, the intermediate pre-B cell (Ia+CALLA+BI+c $\mu-)$, and finally the "true" pre-B cell $(\mathrm{Ia}+\mathrm{CALLA}+\mathrm{Bl}+\mathrm{c} \mu+)$. The cellular

Received for publication 22 February 1982 and in revised form 20 April 1982. origin of the remaining Ia $+C A L L A-B 1-c \mu-$ form of non-T cell ALL (20\%) is still unknown.

\section{INTRODUCTION}

Leukemic cells from $\sim 80 \%$ of patients with acute lymphoblastic leukemia (ALL) ${ }^{1}$ lack both cell surface immunoglobulin and $\mathrm{T}$ cell antigens. Although these cells are devoid of conventional B or $\mathrm{T}$ cell antigens, they express a variety of cell surface markers including the common acute lymphoblastic leukemia antigen (CALLA) (1-5) and the Ia-like antigens (Ia) $(6,7)$. The cellular origin of these non-T ALL has been the subject of numerous studies that, for the most part, suggest that they are of B cell origin. Several laboratories have demonstrated that tumor cells from $\sim 20-30 \%$ of patients with non-T ALL have a pre-B cell phenotype since they express intracytoplasmic $\mu$-chain but lack cell surface immunoglobulin (8-10). In addition, nonT cell ALL cells express B cell surface markers other than immunoglobulins (11-13).

In a recent study, we described a monoclonal antibody, termed anti-B1, which identifies a unique B cell surface differentiation antigen present on all normal B lymphocytes $(13,14)$. This antibody was also reactive with all $B$ cell lymphomas and $B$ cell chronic lymphocytic leukemias (CLL) expressing monoclonal surface $\mathrm{k}$ or $\lambda$ light chains (13). In addition, tumor cells from $\sim 50 \%$ of non-T ALL were reactive with anti-Bl suggesting a $B$ cell lineage of these tumors.

\footnotetext{
${ }^{1}$ Abbreviations used in this paper: ALL, acute lymphoblastic leukemia; Ara-C, cytosine arabinoside; CALLA, common acute lymphoblastic leukemia antigen; CLL, chronic lymphocytic leukemia, DMSO, dimethyl sulfoxide, FCS, fetal calf serum, $\left[{ }^{3} \mathrm{H}\right] \mathrm{TdR}$, triated thymidine, PBS, phosphatebuffered saline, PHA-LCM, phytohemagglutinin-stimulated leukocyte conditioned medium, sIg-surface immunoglobulin, TPA, 12-O-tetra-decanoylphorbol-13-acetate.
} 
Thus, the non-T ALL could be divided into the following groups: (a) Ia+CALLA+Bl+ $(50 \%)$ (b) $\mathrm{Ia}+\mathrm{CALLA}+\mathrm{Bl}-(30 \%) ;$ and (c) Ia+CALLA$\mathrm{Bl}-(20 \%)$.

In the present study, non-T cell ALL lines and tumor cells from patients with non-T cell ALL that were not reactive with anti-Bl antibody (Ia+CALLA+B1-) were studied in vitro with a variety of agents known to promote cellular differentiation. The studies to be described below demonstrate that both phorbol diester (TPA) and phytohemagglutinin conditioned leukocyte media (PHA-LCM) can induce the expression of the $\mathrm{Bl}$ antigen on CALLA+Ia+B1- non-T cell leukemic lines. In addition, tumor cells from eight of nine patients with Ia+CALLA+BI- non-T ALL can also be induced to express $\mathrm{Bl}$. These studies support the view that the majority of Ia+CALLA+ non-T cell ALL are of $B$ cell lineage.

\section{METHODS}

Cell lines. Cell lines Laz $221(15), 207^{2}$, and $697^{2}$ were derived from patients with non-T cell ALL. The NALM-1 cell line was derived from a patient with lymphoid blast crisis of chronic myelocytic leukemias (16). The HL-60 cell line was developed from a patient with promyelocytic leukemia (17) and the CEM cell line was developed from a patient with a $\mathrm{T}$ cell lymphoblastic lymphoma (18). Laz 221, NALM-1, HL-60, and CEM were kindly provided by Dr. Herbert Lazarus (Sidney Farber Cancer Institute, Boston, MA) and lines 207 and 697 were kindly provided by Dr. Harry Findley, Jr. (Emory University School of Medicine, Atlanta, GA). Cells were maintained in continuous culture in Eagle's minimal essential medium (Microbiological Associates, Walkersville, MD) supplemented with $10 \%$ fetal calf serum (FCS) (Microbiological Associates), $50 \mathrm{U} / \mathrm{ml}$ penicillin, $50 \mu \mathrm{g} / \mathrm{ml}$ streptomycin, $1 \mathrm{mM}$ sodium pyruvate, $1 \%$ solution of nonessential amino acids $(0.1 \mathrm{mM}$ each), and 4 $\mathrm{mM}$ L-glutamine (media is referred to as MEM-FCS).

Leukemic cells. All patients in this study were evaluated at the Sidney Farber Cancer Institute, the Children's Hospital Medical Center, Peter Bent Brigham Hospital, or the Beth Israel Hospital. The diagnosis of acute lymphoblastic leukemia was made using standard, clinical, morphologic, and cytochemical criteria (19). Heparinized peripheral blood or bone marrow was collected from leukemic patients before the administration of chemotherapeutic agents or blood products. Mononuclear cells were separated from these specimens by Ficoll-Hypaque density centrifugation as previously described (20). Tumor cells were readily distinguishable from normal lymphocytes by Wright-Giemsa morphology, and all neoplastic preparations selected for this study had $>75 \%$ abnormal cells. Isolated tumor cells were cryopreserved in $10 \%$ dimethylsulfoxide and $20 \%$ fetal calf serum at $-196^{\circ} \mathrm{C}$ in the vapor phase of liquid nitrogen until the time of study. Tumor cells from patients for this study had previously been shown to express the following cell surface phenotypes: Ia+CALLA+B1- or Ia+CALLA-B1-.

\footnotetext{
${ }^{2}$ Findley, H. W., Jr., M. D. Cooper, and A. H. Ragab. Submitted for publication.
}

\section{Inducing agents}

Phorbol diester. 12-O-tetradecanoylphorbol-13-acetate (TPA) (Sigma Chemical Co., St. Louis, MO) was initially dissolved in acetone $0.16 \mathrm{mM}$ and then diluted in culture medium to an appropriate final molar concentration. Medium containing an equivalent amount of acetone $(0.01 \%)$ served as control. The TPA was kindly provided by Dr. Robert Todd, III (Sidney Farber Cancer Institute).

Leukocyte conditioned medium. PHA-LCM was prepared according to the method of Aye (21). In brief, peripheral blood mononuclear cells were incubated at a concentration of $1 \times 10^{6} \mathrm{cells} / \mathrm{ml}$ in RPMI 1640 supplemented with $10 \%$ FCS plus $4 \mu \mathrm{g} / \mathrm{ml}$ of PHA at $37^{\circ} \mathrm{C}$ in a humidified atmosphere of $5 \% \mathrm{CO}_{2}$ in air. Supernatant was harvested at $96 \mathrm{~h}$. Control conditioned medium was prepared similarly but without the addition of leukocytes.

Dimethyl sulfoxide. Dimethyl sulfoxide (DMSO) (Fisher Scientific) was diluted with MEM-FCS to appropriate percentage DMSO. Control culture medium was MEM-FCS.

Cytosine arabinoside (Ara-C). Ara-C (Sigma Chemical Co.) was prepared fresh daily and diluted with MEM-FCS to appropriate molar concentration. Control culture media was MEM-FCS.

\section{Culture conditions for the induction of $\mathrm{B} 1$}

Varying concentrations of cells were resuspended in MEM-FCS containing either PHA-LCM or TPA and cultured for varying time intervals in $25-\mathrm{cm}^{2}$ tissue culture flasks (Corning Glass Works, Corning, NY) at $37^{\circ} \mathrm{C}$ in a humidified atmosphere in $5 \% \mathrm{CO}_{2}$ in air. At the end of the culture period, experimental and control cultures were resuspended by vigorous pipetting, washed, and resuspended in medium containing $20 \%$ human pooled AB serum. Aliquots were taken at appropriate times for cell counting, histochemical staining, and screening for the expression of $\mathrm{Bl}$, cytoplasmic $\mu$, and other B and T cell antigens. TPA cultured cells were subjected to Ficoll-Hypaque density gradient centrifugation to sediment dead cells and debris prior to further analysis. Cell viability was assayed by trypan blue exclusion.

\section{Monoclonal antibodies}

The preparation and characterization of monoclonal antibodies used in this study have been previously described in detail. All antibodies used in this study were ascites fluid and used at saturated binding concentrations. Control ascites represented isotype identical nonreactive ascites. Monoclonal anti-I2 (Ia) defines a nonpolymorphic Ia-like antigen expressed on B cells, monocytes, and activated T cells (22). Monoclonal antibodies to immunoglobulin heavy chains $\mu$, $\delta, \gamma$, and light chains $k$ and $\lambda$ have been previously described (23). In addition, affinity purified directly fluoresceinated rabbit anti-human $\mu$ and $\gamma$ antibodies were also used (Dako Immunoglobulins, Accurate Chemical Co., CA). Monoclonal anti-Bl has previously been shown to be specific for normal $B$ cells with the exception of terminally differentiated plasma cells and is also reactive with malignant cells of $B$ lineage $(13,14,23)$. Monoclonal anti-B2 defines a $B$ cell-specific antigen that has a more limited expression than $\mathrm{Bl}$ and is found on normal and malignant $B$ lymphocytes that express surface immunoglobulins that have not undergone "transformation" (24). The CALLA antigen is defined by the J5 monoclonal antibody that defines a $100,000-\mathrm{mol}$ wt glycoprotein expressed on the leukemic cells of $80 \%$ of patients with non-T cell ALL and 30-50\% of patients with chronic 
myelocytic leukemia in blast crisis (1-6). A small number of normal bone marrow cells and fetal liver cells also express CALLA. It has been recently shown that CALLA is also found on $\sim 40 \%$ of patients with $T$ cell lymphoblastic lymphoma and most patients with Burkitt's lymphoma, and on nodular poorly differentiated lymphocytic lymphoma (25). The $T$ cell surface antigens (T3, T4, T5/8, and T6) are defined by a series of monoclonal antibodies previously described in detail $(26,27)$.

\section{Indirect immunofluorescence}

In brief, 1-2 $\times 10^{6}$ cells were treated with either $0.1 \mathrm{ml}$ of a 1:500 dilution of the specific monoclonal antibody to be tested or $0.1 \mathrm{ml}$ of a 1:500 dilution of an unreactive control antibody of a similar isotype, incubated at $4^{\circ} \mathrm{C}$ for $30 \mathrm{~min}$, and washed three times. These cells were then reacted with $0.1 \mathrm{ml}$ of a 1:40 dilution of fluorescein conjugated goat antimouse IgG (G/M-FITC) (Meloy Laboratories, Springfield, VA), incubated at $4^{\circ} \mathrm{C}$ for $30 \mathrm{~min}$, washed three times, and analyzed as previously described (28). Intensity of fluorescence was determined for 10,000 cells in each population on a fluorescence-activated cell sorter and compared with the fluorescence of a control nonreactive ascites. A displacement of the histogram for the test monoclonal antibody was scored as positive compared with the histogram of an unreactive isotype identical monoclonal antibody. In addition, for each test sample, a quantitative assessment of the percentage of positive cells was made (number of cells reactive with test monoclonal antibody minus number of cells reactive with unreactive isotype identical monoclonal antibody divided by 10,000 total cells tested).

\section{Cytoplasmic immunoglobulin assay}

Cells containing cytoplasmic immunoglobulin (cIg) were enumerated by indirect immunofluorescence by a modification of previously described techniques (23). Cytocentrifuge preparations of culture cells were fixed in $95 \%$ ethanol at $4^{\circ} \mathrm{C}$ for $20 \mathrm{~min}$. Slides were then washed in phosphatebuffered saline (PBS) for $20 \mathrm{~min}$, exposed to either directly fluoresceinated affinity purified rabbit anti-mouse $\gamma$ or $\mu$ (Dako Immunoglobulins) at a 1:200 dilution, and incubated for $20 \mathrm{~min}$ at room temperature in a humidified atmosphere. Slides were then washed for $\mathbf{2} \mathrm{h}$ in PBS. After washing, slides were mounted in $50 \%$ (vol/vol) glycerin in PBS, and cells containing cIg were counted on Zeiss Fluorescent Microscope (Carl Zeiss, Inc., New York). At least 200 cells were counted per slide.

\section{Inhibition of DNA synthesis}

To evaluate whether induction of Bl led to inhibition of DNA synthesis, cells at varying intervals in culture were transferred to microculture plates with $1 \times 10^{5}$ cells per well. $4 \mathrm{~h}$ before termination, triplicate cultures were pulsed with $0.25 \mu \mathrm{Ci}\left(1 \mathrm{Ci}=3.7 \times 10^{10}\right.$ becquerels $)\left[{ }^{3} \mathrm{H}\right]$ thymidine. Cultures were harvested with an automatic cell harvester (Brandel, Gaithersberg, MD) onto glass filter strips, dried, and assayed by scintillation spectroscopy (Packard Instruments, Inc., Downers Grove, IL). Triplicate samples were assayed and expressed as mean $\pm \mathrm{SD}$.

\section{RESULTS}

Cell surface phenotype of non-T cell ALL lines. Three cell lines derived from patients with non-T cell
ALL (Laz 221, 697 and 207) and a cell line derived from a patient with a lymphoid blast crisis of chronic myelocytic leukemia (NALM-1) were studied with a panel of monoclonal antibodies. As shown in Table I, all four cell lines are Ia and CALLA positive, as measured by indirect immunofluorescence. Laz 221, 697, and NALM-1 are weakly reactive with anti- $\mu$ antibody (monoclonal and heteroantisera) by both surface and cytoplasmic staining. Laz 221, 697, and 207 were unreactive with anti-B1, whereas NALM-1 was weakly reactive. All four cell lines were unreactive with other monoclonal antibodies known to react with $B$ cells including anti-B2, anti-IgG, anti-IgD, anti- $\kappa$, and anti$\lambda$. Although not shown in Table $I$, these four cell lines were unreactive with specific $T$ cell monoclonal antibodies including T3, T4, T5/8, and T6.

Induction of $B$ cell antigens on non- $T$ cell $A L L$ lines. Laz 221 was cultured in vitro in the presence of TPA or PHA-LCM for $48 \mathrm{~h}$ and the cell surface phenotype analyzed. As shown in Fig. 1, the Bl antigen could be readily detected following treatment with InM TPA or 20\% PHA-LCM. B1 antigen was not induced by control media, PHA, pokeweed mitogen, or pokeweed mitogen conditioned media (data not shown). In addition to the expression of $\mathrm{Bl}$ on the $\mathrm{Laz}$ 221 cells, there was also a loss of cell surface and cytoplasmic $\mu$-heavy chains. CALLA and Ia antigens, on the other hand, were unaffected by TPA or PHA-LCM. As shown in Fig. 2, similar results were obtained with cell lines 697, 207, and NALM-1. 697 became strongly Bl antigen positive and both surface and cytoplasmic $\mu$ became undetectable. Line 207 , in contrast, remained $\mu$-negative throughout and clearly developed the Bl antigen. NALM-1 was weakly anti-Bl reactive to start and became much more strongly $B 1$ positive after culture with TPA. The morphology of the cell lines appeared unchanged by Wright-Giemsa staining when cells were cultured with media, TPA, or PHALCM for $5 \mathrm{~d}$ in vitro.

TABLE I

Cell Surface Phenotype of Non-T Lymphoblastic Cell Lines

\begin{tabular}{lcccc}
\hline & \multicolumn{4}{c}{ Cell line } \\
\cline { 2 - 5 } Surface antigen & Laz 221 & 697 & 207 & NALM-1 \\
\hline Ia & $+++^{\circ}$ & +++ & ++ & +++ \\
CALLA & ++ & ++ & + & ++ \\
sIg & $+(\mu)$ & $+(\mu)$ & 0 & $+(\mu)$ \\
cIg & $+(\mu)$ & $+(\mu)$ & 0 & $+(\mu)$ \\
B1 & 0 & 0 & 0 & $+(30 \%)$ \\
B2 & 0 & 0 & 0 & 0 \\
\hline
\end{tabular}

- 0 , nonreactive, + , weakly reactive; ++ , moderately reactive; +++ , strongly reactive (see Fig. 2). 


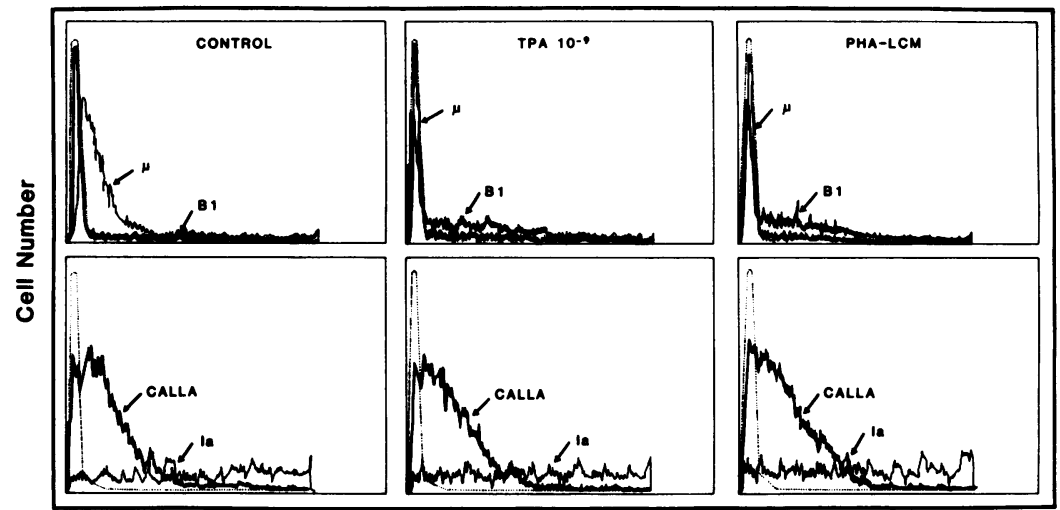

Fluorescence Intensity

Figure 1 Induction of $\mathrm{Bl}$ on Laz 221 cells. Laz 221 cells were cultured in the presence of media, TPA ( $1 \mathrm{nM}$ ) of PHA-LCM $(30 \%)$ for $48 \mathrm{~h}$. At the end of the culture period, viable cells were evaluated for the expression of surface $\mu, \mathrm{Bl}, \mathrm{CALLA}$, and Ia by indirect immunofluorescence on the fluorescence-activated cell sorter. Control antibody (13) is an IgG2a antibody unreactive with Laz 221 cells. It can be seen from the fluorescence histograms that TPA and PHA-LCM induced the expression of Bl and the loss of surface $\mu$ on a subpopulation of Laz 221 cells, whereas the expression of Ia and CALLA appear unchanged.

To evaluate the effect of TPA on the expression of B1, Laz 221 cells were cultured for $5 \mathrm{~d}$ with varying amounts of TPA. As shown in Table II, concentrations of $10 \mathrm{pM}$ to $1 \mathrm{pM}$, TPA had no effect on cytoplasmic $\mu, \mathrm{Bl}$, or Ia expression. At $0.1 \mathrm{nM}$ TPA, B1 was weakly expressed and the number of cytoplasmic $\mu$-positive cells decreased slightly (Table II). The optimal concentration to promote the expression of $\mathrm{Bl}$ was $1 \mathrm{nM}$ TPA. At this concentration, the number of Laz 221 cells that expressed Bl was $42 \%$ after $2 \mathrm{~d}$ and $71 \%$ after $3 \mathrm{~d}$ (Table II). In the absence of TPA, $\sim 2 \%$ of cells expressed Bl. At $0.1 \mu \mathrm{M}$ and $10 \mathrm{nM}$ TPA, the number of viable cells decreased markedly. Cytoplasmic and cell surface $\mu$ decreased at concentrations of TPA that induced B1 expression (Figs. 1 and 2, Table II). Ia and CALLA, in contrast, were unchanged at any dose of TPA or PHA-LCM. In addition, if Laz 221 cells were cultured sequentially with PHA-LCM or TPA or the reverse, the resulting cell surface phenotype was identical to that obtained with either of the agents alone. Other B cell determinants including sIgG, $\kappa, \lambda$, or B2 were not noted to appear after TPA or PHA-LCM treatment. Similarly, $T$ cell antigens did not appear after TPA or PHA-LCM.

DMSO (0.5-5\%) and Ara-C (10 mM-10 nM) were also tested for their capacity to induce $B$ cell antigens since these agents have been shown to promote cellular differentiation. Neither had an effect on the appearance of $\mathrm{Bl}$, other $\mathrm{B}$ cell antigens, or $\mathrm{T}$ cell antigens.

Additional experiments were undertaken to investigate whether the $\mathrm{Bl}$ antigen could be induced on cell

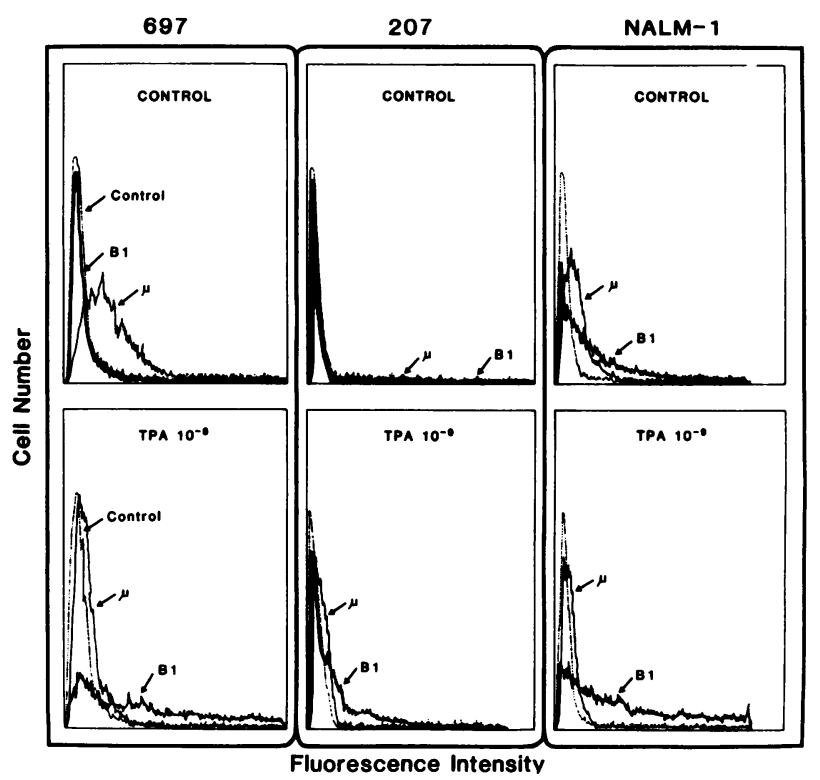

Figure 2 Induction of $\mathrm{Bl}$ on other non-T ALL cell lines. Cell lines were cultured in the presence of control media or TPA $1 \mathrm{nM}$ for $48 \mathrm{~h}$ and then assayed for reactivity with antiBl or anti- $\mu$ by indirect immunofluorescence. As seen in the left-hand panel, 697 cells that were initially B1 negative, surface $\mu$ positive became strongly $B 1$ positive and the expression of surface $\mu$ decreased. Line 207 (center panel) was initially Bl negative and surface $\mu$ negative. With TPA induction, 207 became $B 1$ positive but remained surface $\mu$ negative. Finally, NALM-1 cells (righthand panel) were initially B1 and surface $\mu$ positive and with TPA became more $\mathrm{Bl}$ positive and showed decreased expression of surface $\mu$. 
TABLE II

TPA Induction of B1 on LAZ 221 Cells

\begin{tabular}{|c|c|c|c|c|c|c|c|c|}
\hline \multirow[b]{2}{*}{ TPA concentration } & \multirow[b]{2}{*}{$\begin{array}{l}\text { Time in } \\
\text { culture }\end{array}$} & \multirow{2}{*}{$\begin{array}{l}\text { Number of viable } \\
\text { cells } \times 10^{6} / \mathrm{ml}\end{array}$} & \multicolumn{6}{|c|}{ Number of viable cells expressing antigen $\times 10^{\circ} / \mathrm{ml}$} \\
\hline & & & B1 & & $\mathrm{C} \mu^{\bullet}$ & & Ia & \\
\hline & $d$ & & & $\%$ & & $\%$ & & $\%$ \\
\hline 0 & 0 & 1.0 & $0 t$ & $2 \S$ & 0.8 & 80 & 0.9 & 90 \\
\hline 0 & 2 & 1.6 & 0 & $\mathbf{0}$ & 1.4 & 87 & 1.6 & 100 \\
\hline $1 \mathrm{pM}$ & 2 & 1.8 & 0 & 0 & 1.5 & 83 & 1.7 & 94 \\
\hline $10 \mathrm{pM}$ & 2 & 1.7 & 0 & 0 & 1.2 & 70 & 1.6 & 94 \\
\hline $0.1 \mathrm{nM}$ & 2 & 1.5 & 0.2 & 10 & 0.9 & 60 & 1.5 & 100 \\
\hline $1 \mathrm{nM}$ & 2 & 1.6 & 0.7 & 41 & 0.3 & 18 & 1.5 & 93 \\
\hline $10 \mathrm{nM}$ & 2 & 0.9 & 0.6 & 65 & 0.1 & 5 & 0.8 & 88 \\
\hline $0.1 \mu \mathrm{M}$ & 2 & 0.5 & 0.4 & 78 & 0.1 & 14 & 0.5 & 100 \\
\hline 0 & 3 & 2.2 & 0 & 2 & 1.8 & 81 & 1.9 & 86 \\
\hline $0.1 \mathrm{nM}$ & 3 & 1.9 & 0.1 & 7 & 1.6 & 84 & 1.6 & 84 \\
\hline $1 \mathrm{nM}$ & 3 & 1.7 & 1.2 & 70 & 0.1 & 5 & 1.4 & 82 \\
\hline $10 \mathrm{nM}$ & 3 & 0.7 & 0.4 & 57 & 0 & 0 & 0.7 & 100 \\
\hline 0 & 5 & 3.0 & 0.1 & 3 & 2.7 & 90 & 2.5 & 83 \\
\hline $0.1 \mathrm{nM}$ & 5 & 2.1 & 0.3 & 12 & 1.7 & 80 & 2.0 & 95 \\
\hline $1 \mathrm{nM}$ & 5 & 0.8 & 0.7 & 87 & 0 & 0 & 0.8 & 100 \\
\hline $10 \mathrm{nM}$ & 5 & 0.3 & 0.2 & 66 & 0 & 0 & 0.2 & 66 \\
\hline
\end{tabular}

- Cytoplasmic $\mu$.

$\ddagger$ Number of viable cells expressing antigen $\times 10^{6} / \mathrm{ml}$.

$\$ \%$, Number of viable cells expressing antigen $\times 10^{6} / \mathrm{ml}$-Total number of viable cells $\times 10^{6} / \mathrm{ml} \times 100$.

lines of other origins. A $\mathrm{T}$ cell leukemic line (CEM) and a promyelocytic leukemic line (HL-60) were cultured with TPA $(0.1 \mu \mathrm{M}-0.1 \mathrm{nM})$ or PHA-LCM (10$30 \%$ ) and followed for $5 \mathrm{~d}$ for the expression of $\mathrm{Bl}$ and other $B$ cell antigens. CEM and HL-60 did not develop $\mathrm{B} 1$ or any other B cell antigens (B2 or sIg). In contrast, under the identical conditions, these lines can be induced to express distinct $\mathrm{T}$ cell and myeloid antigens $(29,30)$.

Inhibition of DNA synthesis with the expression of $B 1$. The number of viable cells did not increase in cell cultures induced to express Bl with TPA or PHALCM. As shown in Fig. 3 (upper panel), there was no increase in cell number over $4 \mathrm{~d}$ in a culture containing Laz 221 cells and $1 \mathrm{nM}$ TPA. Bl antigen positive cells appeared as early as 12-24 $\mathrm{h}$ and reached a maximum after $3 \mathrm{~d}$ (Fig. 3, middle panel). With the expression of B1 the synthesis of DNA as measured by tritiated thymidine incorporation $\left(\left[{ }^{3} \mathrm{H}\right] \mathrm{TdR}\right)$ was dramatically inhibited. Inhibition was seen as early as $12 \mathrm{~h}$ and was complete by $48 \mathrm{~h}$. All four lines had a significant degree of inhibition of DNA synthesis by TPA or PHALCM (Table III). Cell lines were cultured with media, TPA, or PHA-LCM and analyzed on 7 consecutive d for viability, number of cells which expressed Bl, and inhibition of DNA synthesis. Table III summarizes the data for all four cell lines after $2 \mathrm{~d}$ in culture. As shown, the expression of $\mathrm{Bl}$ was accompanied by at least $50 \%$ inhibition of DNA synthesis.

Although significant inhibition of DNA synthesis seemed to correlate with $\mathrm{Bl}$ expression, additional experiments suggested that inhibition of DNA synthesis was not sufficient to promote Bl expression. Laz 221 cells were cultured with either TPA, PHA-LCM, DMSO, or Ara-C. Over a wide range of doses, all agents could inhibit DNA synthesis but only PHA-LCM and TPA could induce Bl expression (data not shown). 1\% DMSO inhibited DNA synthesis by $78 \%$, and Ara-C (10 and $0.1 \mu \mathrm{M}$ ) inhibited DNA synthesis by upwards of $99 \%$ after $48 \mathrm{~h}$ of culture but had no effect on B1 expression. Correlation of inhibition of DNA synthesis with cell viability excluded the possibility that cell death was the cause of the inhibition of DNA synthesis. In response to DMSO and Ara-C, no cells were induced to express Bl and none lost cytoplasmic $\mu$ or acquired new antigens.

Since only a fraction of stimulated cells (TPA or PHA-LCM) expressed B1, an attempt was made to correlate antigen expression with inhibition of DNA synthesis. After $48 \mathrm{~h}$ in culture, $\sim 30 \%$ of NALM-1 

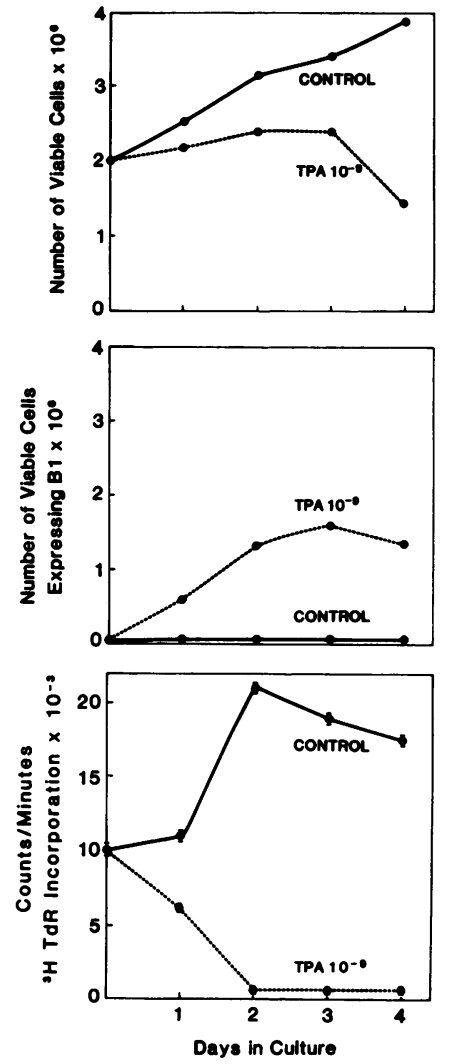

Figure 3 Cellular proliferation and the expression of B1. Laz 221 cells were cultured in the presence of control media or TPA $1 \mathrm{nM}$ for $4 \mathrm{~d}$. As seen in the upper panel, the number of Laz 221 cells doubled over the 4-d period in the presence of control media. In contrast, cells treated with 1 nM TPA did not proliferate. Laz 221 cells cultured with 1 nM TPA expressed $\mathrm{Bl}$ with a peak number of positive cells at $3 \mathrm{~d}$ (center panel). Cells in the presence of control media did not express Bl. The synthesis of DNA was evaluated by incorporation of $\left[{ }^{3} \mathrm{H}\right] \mathrm{TdR}$. Laz 221 cells in the presence of control media or TPA $1 \mathrm{nM}$ were pulsed for $4 \mathrm{~h}$ with $\left[{ }^{3} \mathrm{H}\right] \mathrm{TdR}$ and triplicate cultures were harvested and counted. As seen in the lower panel, the TPA-treated cells ceased to incorporate $\left[{ }^{3} \mathrm{H}\right] \mathrm{T} d \mathrm{R}$ whereas control cultures showed rapid incorporation.

cells express B1. These NALM-1 cells were directly stained with fluoresceinated anti-Bl and then sorted into $B 1$ antigen positive and $B 1$ antigen negative populations. The $\mathrm{Bl}$ antigen negative and positive populations were pulsed with $\left[{ }^{3} \mathrm{H}\right] \mathrm{TdR}$ for $4 \mathrm{~h}$ in vitro. Bl antigen positive cells had minimal $\left[{ }^{3} \mathrm{H}\right] \mathrm{TdR}$ incorporation, whereas $B 1$ antigen negative cells had significant incorporation of $\left[{ }^{3} \mathrm{H}\right] \mathrm{TdR}$. Similar results were obtained when Laz 221 cells were induced with $1 \mathrm{mM}$ TPA to express Bl. Cells were cultured for $48 \mathrm{~h}$ at $37^{\circ} \mathrm{C}$ and then directly stained with fluoresceinated anti-Bl and sorted into Bl positive and negative populations. As shown in Table IV, the Bl antigen positive population showed minimal uptake of $\left[{ }^{3} \mathrm{H}\right] \mathrm{TdR}$, whereas the negative population incorporated $\left[{ }^{3} \mathrm{H}\right] \mathrm{TdR}$ maximally. This data is consistent with the evidence presented above showing decreased DNA synthesis with appearance of the $B 1$ antigen.

Induction of $B 1$ on tumor cells from patients with B1 antigen negative non-T cell ALL. Tumor cells from patients with $B 1$ antigen negative non-T ALL were cultured with TPA in an attempt to induce the expression of $\mathrm{B} 1$. Nine patients with $>75 \%$ Ia +CALLA+Bl - tumor cells were studied. Tumor cells from eight of nine patients could be induced to express Bl in the presence of $1 \mathrm{nM}$ TPA for $48 \mathrm{~h}$ (Table V). An example of TPA-induced Bl expression is shown in Fig. 4 (patient 3). No consistent changes were noted for the expression of either Ia or CALLA. More importantly, these patients started as cytoplasmic $\mu$-negative and became cytoplasmic $\mu$-positive at the end of $48 \mathrm{~h}$ with $1 \mathrm{nM}$ TPA. These results are quite different from those obtained with cell lines wherein cytoplasmic $\mu$ diminished rather than increased with TPA. No difference in the number of viable tumor cells between control cultures and TPA-stimulated cultures was noted over the $48 \mathrm{~h}$, suggesting that a $\mathrm{Bl}$ antigen positive (B1 positive, cytoplasmic $\mu$ positive) subset of cells was not expanded. In addition, an attempt to induce $B 1$ was undertaken on tumor cells isolated from five patients with Ia+CALLA-Bl- non-T cell ALL. Viable tumor cells were cultured with either control media, $10 \mathrm{nM}$ TPA, or $1 \mathrm{nM}$ TPA. After $48 \mathrm{~h}$, tumor cells were tested for cell surface expression of Ia, CALLA, and Bl induced by TPA. In no instance was B1 or CALLA induced by TPA (data not shown). Moreover, there was no change in expression of Ia.

\section{DISCUSSION}

In several recent reports, we have described the preparation and characterization of a monoclonal antibody (anti-B1), which is reactive with a novel differentiation antigen expressed on human $B$ cells and on those cells destined to differentiate into immunoglobulin secreting cells following pokeweed mitogen stimulation (13, $14,22-24)$. The $B 1$ antigen is expressed on surface immunoglobulin positive B lymphocytes isolated from peripheral blood and lymphoid organs and is not found on resting or activated $T$ cells, monocytes, null cells, granulocytes, erythrocytes, or platelets. In lymphoid tissues, the Bl antigen is primarily localized in the lymphoid follicles, i.e. $B$ cell regions (31). When surface immunoglobulin-bearing B cells are stimulated with pokeweed mitogen, the Bl antigen is lost from the cell surface. The loss of $\mathrm{Bl}$ is accompanied by the development of presecretory cytoplasmic IgG and the appearance of plasma cells suggesting that B1 is a "pan-B cell" differentiation antigen (23). Additional 
TABLE III

Induction of BI on Non-T Lymphoblastic Cell Lines: Dose Response and Correlation with DNA Synthesis

\begin{tabular}{|c|c|c|c|c|}
\hline Cell line & Inducing agent & $\begin{array}{c}\text { Number of viable } \\
\text { cells cultured } \\
\text { with media } \times 10^{8} / \mathrm{ml}\end{array}$ & $\begin{array}{c}\text { Number of viable } \\
\text { B1 }+ \text { cells } \times 10^{\circ} / \mathrm{ml}\end{array}$ & $\begin{array}{l}\text { \% inhibition } \\
\text { of DNA } \\
\text { synthesis }\end{array}$ \\
\hline & & & $\%$ & \\
\hline \multirow{5}{*}{ Laz 221} & Media & 2.8 & $0.1(2)$ & $\mathbf{0}$ \\
\hline & TPA $0.1 \mathrm{nM}$ & 2.6 & $0.1(3)$ & 9 \\
\hline & TPA 1 nM & 2.0 & $1.3(63)$ & 97 \\
\hline & PHA-LCM 15\% & 2.8 & $0.5(16)$ & 37 \\
\hline & PHA-LCM $30 \%$ & 2.4 & $0.9(38)$ & 55 \\
\hline \multirow{5}{*}{ NALM-1 } & Media & 3.2 & $0.8(26)$ & $\mathbf{0}$ \\
\hline & TPA $0.1 \mathrm{nM}$ & 3.0 & $0.9(30)$ & 17 \\
\hline & TPA 1 nM & 2.8 & $2.2(77)$ & 82 \\
\hline & PHA-LCM 15\% & 3.2 & $0.8(25)$ & 10 \\
\hline & PHA-LCM $30 \%$ & 3.0 & $1.9(64)$ & 65 \\
\hline \multirow{3}{*}{697} & Media & 4.0 & $0.4(9)$ & $\mathbf{0}$ \\
\hline & TPA $0.1 \mathrm{nM}$ & 4.0 & $0.3(8)$ & 12 \\
\hline & TPA $1 \mathrm{nM}$ & 3.6 & $1.9(54)$ & 58 \\
\hline \multirow{3}{*}{207} & Media & 4.5 & $0.1(27)$ & 0 \\
\hline & TPA $0.1 \mathrm{nM}$ & 4.4 & $0.1(2)$ & 8 \\
\hline & TPA 1 nM & 4.2 & $1.3(31)$ & 72 \\
\hline
\end{tabular}

evidence that $\mathrm{Bl}$ is a "pan-B cell" differentiation antigen was derived from examination of the human B cell malignancies that encompass the entire spectrum of $\mathrm{B}$ cell differentiation (13). The $\mathrm{Bl}$ antigen is present on the cell surface of tumor cells isolated from over 100 patients with B cell non-Hodgkin's lymphoma and 100 patients with B cell CLL. In addition, the Bl antigen was absent from cells isolated from patients with multiple myeloma confirming the evidence that the Bl antigen is lost from the terminally differentiated B lymphocyte.

In contrast to the expression of $\mathrm{B} 1$ on all surface immunoglobulin bearing $B$ cells, the identification of the earliest B cell that expresses the Bl antigen has been more difficult. Since leukemias and lymphomas are thought to represent "relatively" fixed stages of normal differentiation, they may provide an important model for the study of normal hematopoietic differentiation (32). Moreover, tumor cells have been induced by a variety of promoters of differentiation to progress along normal differentiative pathways (33, 34). Presumably the genetic commitment towards a specific differentiation pathway has already been established in these cells and the inducing agents may merely induce a transcriptional event. In previous studies, we showed that approximately half of the non-

TABLE IV

Reduction of DNA Synthesis of B1 Antigen-positive Cells

\begin{tabular}{lllr}
\hline Cell line & \multicolumn{1}{c}{ Agent } & \multicolumn{1}{c}{ Test population } & [PHTdR incorporation \\
\hline \multirow{2}{*}{ A NALM-1 } & Media & Bl-FITC unsorted & $7,368 \pm 480$ \\
& Media & Bl $+\$$ & $1,234 \pm 146$ \\
& Media & Bl- $\$$ & $16,664 \pm 842$ \\
B Laz 221 & Media & Bl-FITC unsorted & $20,800 \pm 780$ \\
& TPA l nM & B1-FITC unsorted & $4,323 \pm 240$ \\
& TPA l nM & B1+ & $324 \pm 86$ \\
& TPA l nM & B1- & $26,300 \pm 942$ \\
\hline
\end{tabular}

- B1-FITC, unsorted cells treated with directly fluoresceinated anti-B1.

$\downarrow \mathrm{Bl}+$, sorted cells which are reactive with directly fluoresceinated anti-Bl.

$\S \mathrm{Bl}-$, sorted cells which are unreactive with directly fluoresceinated anti-B1. 
TABLE V

TPA Induction of B1 on Tumor Cells from Patients with Non-T ALL

\begin{tabular}{|c|c|c|c|c|c|c|c|c|}
\hline \multirow{2}{*}{$\begin{array}{l}\text { Patient } \\
\text { number }\end{array}$} & \multicolumn{4}{|c|}{ Control } & \multicolumn{4}{|c|}{ TPA stimulated } \\
\hline & Bl & CALLA & Ia & $\mathrm{C}_{\mu}$ & B1 & CALLA & Ia & $\mathrm{C}_{\mu}$ \\
\hline 1 & $0^{\circ}$ & $4+$ & $2+$ & 0 & $1+$ & $4+$ & $3+$ & $1+$ \\
\hline 2 & 0 & $4+$ & $3+$ & 0 & $2+$ & $2+$ & $4+$ & $1+$ \\
\hline 3 & 0 & $3+$ & $4+$ & 0 & $2+$ & $2+$ & $4+$ & $1+$ \\
\hline 4 & 0 & $4+$ & $4+$ & 0 & $1+$ & $1+$ & $4+$ & $2+$ \\
\hline 5 & 0 & $2+$ & $4+$ & 0 & $1+$ & $1+$ & $4+$ & $2+$ \\
\hline 6 & 0 & $2+$ & $3+$ & 0 & 0 & $3+$ & $3+$ & $1+$ \\
\hline 7 & 0 & $2+$ & $3+$ & 0 & $3+$ & $2+$ & $3+$ & $1+$ \\
\hline 8 & 0 & $2+$ & $4+$ & 0 & $2+$ & $2+$ & $4+$ & $1+$ \\
\hline 9 & $\mathbf{0}$ & $4+$ & $4+$ & 0 & $2+$ & $4+$ & $4+$ & $2+$ \\
\hline
\end{tabular}

- $0,<10 \%$ of cells reactive with monoclonal antibody.

$1+, 10-30 \%$ of cells reactive with monoclonal antibody.

$2+, 30-50 \%$ of cells reactive with monoclonal antibody.

$3+, 50-70 \%$ of cells reactive with monoclonal antibody.

$4+,>70 \%$ of cells reactive with monoclonal antibody.

T cell ALL expressed Bl. Moreover, Bl antigen expression was seen in that subgroup of patients that were also CALLA positive. The finding that one-third of Ia+CALLA+ non-T ALL are Bl antigen negative suggested that these cells might correspond to a $\mathrm{B}$ cell differentiative state that was earlier than the "pre-B" cell (represented by the Ia+CALLA+B1+ cell). The present study supports the hypothesis that the $\mathrm{Ia}+\mathrm{CALLA}+\mathrm{B} 1-$ cell precedes the Ia+CALLA+BI+ cell, and therefore, suggests that in normal differentiation these cells may correspond to a "pre-pre-B" B cell.

In this report, four B1-ALL cell lines were induced

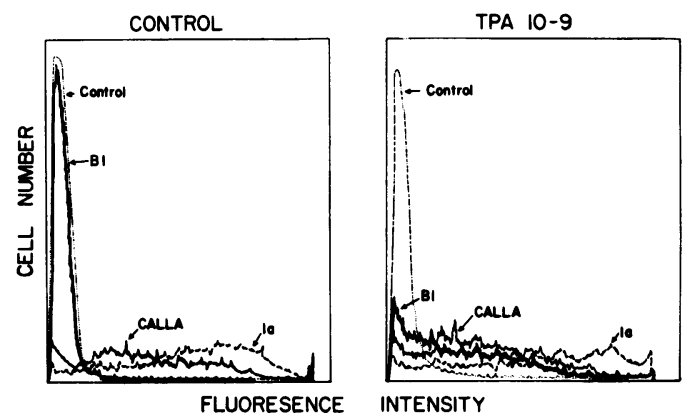

Figure 4 Induction of $\mathrm{Bl}$ on a patient with Ia +CALLA+B1- non-T cell ALL. Tumor cells from a patient with Ia + CALLA $+B 1-\mu-$ non-T cell ALL were cultured in the presence of $1 \mathrm{nM}$ TPA for $48 \mathrm{~h}$. At the end of the culture period, viable cells were evaluated for the expression of $B 1$, CALLA, and Ia by indirect immunofluorescence. It can be seen from the fluorescence histograms that culture with control media did not lead to a change in Bl, CALLA, or Ia. Culture with $1 \mathrm{nM}$ TPA induced Bl expression without change in the expression of CALLA or Ia. with TPA or PHA-LCM to express B1. With the induction of $B 1$, cytoplasmic or surface $\mu$-heavy chain became undetectable, whereas the expression of CALLA and Ia were unchanged. In addition, no other $B$ cell-associated antigens were induced nor were significant morphologic changes noted. For the induction of $\mathrm{Bl}$, a critical concentration of TPA or PHA-LCM was required as well as an adequate exposure time in vitro. By $48 \mathrm{~h}$ in culture, cells that expressed Bl no longer proliferated or synthesized DNA. Although inhibition of DNA synthesis temporally accompanied B1 expression, other agents known to promote cellular differentiation like DMSO and Ara-C led to significant inhibition of DNA synthesis without inducing B1 expression. These observations suggested that inhibition of DNA synthesis was not sufficient to "trigger" B1 expression. In other experimental systems, inhibition of DNA synthesis has been shown to accompany lymphoid and myeloid differentiation (33-36). Moreover, it has been postulated that as cells differentiate they "leave" the cell cycle (37). The observation that the expression of $\mathrm{Bl}$ is accompanied by inhibition of DNA synthesis provided one line of evidence that these cells have in fact differentiated. Attempts to drive these cells further along the pathway of B cell differentiation with other agents or combinations of agents have been uniformly unsuccessful to date. We have, for example, been unable to induce isotype switching, acquisition of other B cell-associated differentiation antigens (sIgM, sIgD, or B2), or secretion of immunoglobulin. Perhaps the non-T cell ALL lines can only undergo limited differentiation as evidence by $\mathrm{Bl}$ acquisition, loss of cytoplasmic $\mu$, cessation of cell growth, and inhibition of DNA synthesis. 
Our studies also demonstrated that tumor cells isolated from patients with Ia +CALLA + B1- non-T ALL could also be induced to express Bl with TPA (Table V). Although three of the four non-T cell ALL cell lines were cytoplasmic $\mu$ positive (Table I), the leukemic cells from all nine patients with Ia +CALLA+BI- ALL were cytoplasmic $\mu$ negative. Within $48 \mathrm{~h}$ in culture, TPA induced the tumor cells of eight of nine patients to express $\mathrm{Bl}$ and nine of nine patients to express cytoplasmic $\mu$. These results differ from those observed with the non-T ALL cell lines where the Bl negative leukemic cell lines became cytoplasmic $\mu$ negative. Whether the lines represent a unique easily cultured subset of non-T cell ALL defining a unique differentiation state (i.e., Ia + CALLA $+B I-\mu+$ ), an alternative line of differentiation (i.e., Ia+CALLA+Bl- $\mu-\rightarrow$ Ia+CALLA $+\mathrm{Bl}-\mu+\rightarrow \mathrm{Ia}+\mathrm{CALLA}+\mathrm{Bl}+\mu-$ ) or anomalous expression of antigens on a malignant cell is presently unclear. Although the discrepancy between cell lines and tumor cells prevents us from precisely ordering the sequence of expression of cytoplasmic $\mu$ and B1, these studies suggest that stages of $B$ cell differentiation exist; the following (a) Ia+CALLA+B1- - -; (b) Ia +CALLA+B1+ + -; and (c) Ia + CALLA $+\mathrm{BI}+\mu+$. Whether the Ia+ CALLA $+\mathrm{Bl}-\mu+$ phenotype found on cell lines actually appears during ontogeny is unclear. Although the Bl antigen could be induced on tumor cells isolated from patients with Ia+CALLA+B1- non-T ALL, TPA could not induce either CALLA or BI on Ia+CALLA-B1ALL. The cellular origin of this subgroup of patients still is unclear.

Over the last several years, a large number of studies have investigated the cellular origin of non-T cell ALL. Initially, these tumor cells were shown to express Ialike antigens providing the first evidence that these cells might be of B cell origin (7). Subsequently, it was demonstrated that $80 \%$ of $\mathrm{Ia}+$ and non-T cell ALL expressed the CALLA antigen (1-6). Recent studies have shown that CALLA is expressed on a small population of normal bone marrow cells $(0-1 \%)$, regenerating bone marrow (1-3\%) and on fetal liver cells (5-10\%). These observations have led to the view that CALLA is an early B cell-associated antigen. The presence of CALLA on some $T$ cell lymphomas, mature $B$ lymphomas, and a related antigen in the kidney suggests that CALLA is more widely distributed (25, 38). Definitive evidence that a subgroup of non-T cell ALL were of $B$ cell origin came from the observation that tumor cells isolated from $20 \%$ of patients with Ia+CALLA+ non-T cell ALL contained cytoplasmic $\mu$-heavy chains $(8-10)$. Other investigators have observed that some pre-B cell ALL express a phenotype that is "more differentiated" than the cytoplasmic $\mu$ positive ALL (39). They demonstrated that this subgroup of pre-B cell ALL have undergone cytoplasmic immunoglobulin isotype switching and/or light chain production (39). Moreover, the recent studies of Korsmeyer et al. (40) demonstrating immunoglobulin gene rearrangements in several patients with non-T cell ALL provide additional evidence for the notion that non-T cell ALL are of pre-B or pre-pre-B cell origin.

Our observation that the $\mathrm{B} 1$ antigen was expressed on $50 \%$ of non-T cell ALL and on $70 \%$ of CALLA positive non-T cell ALL extended the number of nonT cell ALL that were thought to be of $B$ cell lineage (13). The present study demonstrated that almost all Ia +CALLA+B1- $\mu-$ non-T ALL could be induced to express B1 and cytoplasmic $\mu$ suggesting that most if not all CALLA positive ALL are of B cell lineage. We, therefore, believe that the non-T cell ALL represent a spectrum of early $B$ cell development from the prepre $B$ cell $(\mathrm{Ia}+\mathrm{CALLA}+\mathrm{Bl}-\mu-)$, to the intermediate pre-B cell $(\mathrm{I} a+\mathrm{CALLA}+\mathrm{Bl}+\mu-)$, and finally to the "true" pre-B cell $(\mathrm{Ia}+\mathrm{CALLA}+\mathrm{Bl}+\mu+)$. The cellular origin of ALL that express Ia + but lack CALLA and $\mathrm{Bl}$ is presently unknown. These observations may provide a framework for studies of normal early B cell differentiation.

\section{ACKNOWLEDGMENTS}

The authors would like to thank Mr. John Daley for technical expertise in cell sorting experiments. We would also like to thank Dr. James Griffin and Dr. Donald Kufe for helpful discussions. Finally, we would like to thank Ms. Joan Lindstrom for excellent secretarial assistance during the preparation of this manuscript.

This work was supported by National Institutes of Health grants AI 12069, CA 19589, CA 25369, and CA 028740. Dr. Nadler is a Research Fellow of the Medical Foundation, Inc., Boston, MA. Dr. Ritz is a Special Fellow of the Leukemia Society of America.

\section{REFERENCES}

1. Greaves, M. F., G. Brown, N. T. Rapson, and T. A. Lister 1975. Antisera to acute lymphoblastic leukemia cells. Clin. Immunol. Immunopathol. 4: 67-84.

2. Pesando, J. M., J. Ritz, H. Lazarus, S. Baseman-Costello, S. E. Sallan, and S. F. Schlossman. 1979. Leukemia-associated antigens in ALL. Blood. 54: 1240-1248.

3. Ritz, J., J. M. Pesando, J. Notis-McConarty, H. Lazarus, and S. F. Schlossman. 1980. A monoclonal antibody to human acute lymphoblastic antigen. Nature (Lond.). 283: 583-585.

4. Greaves, M. F. 1981. Monoclonal antibodies as probes for leukemic heterogeneity and hemapoeitic differentiation. In Leukemia Markers. W. Knapp, editor. Academic Press, Inc., New York. 19.

5. Nadler, L. M., J. Ritz, E. L. Reinherz, and S. F. Schlossman. 1981. Cellular origins of human leukemias and lymphomas. In Leukemia Markers. W. Knapp, editor. Academic Press, Inc., New York. pp. 1-17.

6. Fu, S. M., R. J. Winchester, and H. G. Kunkel. 1975. 
The occurrence of the HL-B alloantigens on the cells of unclassified acute lymphoblastic leukemias. J. Exp. Med. 142: 1334-1338.

7. Schlossman, S. F., L. Chess, R. E. Humphries, and J. L. Strominger. 1976. Distribution of Ia-like molecules on the surface of normal and leukemic human cells. Proc. Natl. Acad. Sci. U. S. A. 73: 1288-1292.

8. Vogler, L. B., W. M. Crist, D. E. Bockman, E. R. Pearl, A. R. Lawton, and M. D. Cooper. 1978. Pre-B cell leukemia: a new phenotype of childhood lymphoblastic leukemia. N. Engl. J. Med. 298: 872-878.

9. Brouet, J. C., J. L. Preud'homme, C. Penit, F. Valensi, P. Rouget, and M. Seligmann. 1979. Acute lym phoblastic leukemia with pre-B cell characteristics. Blood. 54: 269273.

10. Greaves, M. F., F. W. Verbi, L. B. Vogler, M. D. Cooper, R. Ellis, K. Ganeshguru, V. Hoffbrand, G. Janossy, and F. J. Bollum. 1979. Antigenic and enzymatic phenotypes of the pre-B subclass of acute lymphoblastic leukemia. Leuk. Res. 3: 353-362.

11. Greaves, M. F., W. Verbi, J. Kemshead, and R. Kennett. 1980. A monoclonal antibody identifying a cell surface antigen shared by common acute lymphoblastic leukemia and B lineage cells. Blood. 56: 1141-1144.

12. Abramson, C., J. Kersey, and T. LeBien. 1981. A monoclonal antibody (BA-1) reactive with cells of human B lymphocytic lineage. J. Immunol. 126: 83-88.

13. Nadler, L. M., P. Stashenko, J. Ritz, R. Hardy, J. M. Pesando, and S. F. Schlossman. 1981. A unique cell surface antigen identifying lymphoid malignancies of $B$ cell origin. J. Clin. Invest. 67: 134-140.

14. Stashenko, P., L. M. Nadler, R. Hardy, and S. F. Schlossman. 1980. Characterization of a human B lymphocyte specific antigen. J. Immunol. 125: 1678-1685.

15. Lazarus, H., E. F. Borell, A. Krishan, D. M. Livingston, K. Harris, S. F. Schlossman, and L. Chess. 1978. Characterization of a unique cell line (Laz 221) from human acute lymphocytic ("Null") cell leukemia. Cancer Res. 38: 1362-1367.

16. Minowada, J., T. Tsubota, M. F. Greaves, and T. R. Walters. 1977. A non-T, non-B human leukemia cell line (NALM-1): established of the cell line and presence of leukemia-associated antigens. J. Natl. Cancer Inst. 59: 83-97.

17. Collin, S. J., R. C. Gallo, and R. E. Gallagher. 1977. Continuous growth and differentiation of human leukemic cells in suspension culture. Nature (Lond.). 270: 347-349.

18. Foley, A., H. Lazarus, S. Farber, B. Ozman, B. Boone, and $R$. McCarthy. 1965. Continuous culture of human lymphoblasts from peripheral blood of a child with acute leukemia. Cancer (Phila.). 18: 522-529.

19. Hayhoe, F. G. J., M. Quagliano and R. Doll. 1964. The cytology and cytochemistry of acute leukemias: a study of 140 cases. Her Majesty's Stationery Office, London.

20. Böyum, A. 1968. Separation of leucocytes from blood and bone marrow. Scand. J. Clin. Lab. Invest. 21(Suppl. 97): $51-76$

21. Aye, M. T., Nihoy, J. E. Till, and E. A. McCulloch. 1974. Studies of leukemic cell populations in culture. Blood. 44: 205-219.

22. Nadler, L. M., P. Stashenko, R. Hardy, J. M. Pesando, E. J. Yunis, and S. F. Schlossman. 1981. Monoclonal antibodies defining serologically distinct HLA-D/DR related Ia-like antigens in man. Hum. Immunol. 1: 77-90.

23. Stashenko, P., L. M. Nadler, R. Hardy, and S. F. Schlossman. 1981. Expression of cell surface markers after hu- man B lymphocyte activation. Proc. Natl. Acad. Sci. U. S. A. 78: $3848-3852$

24. Nadler, L. M., P. Stashenko, R. Hardy, A. van Agthoven, C. Terhorst, and S. F. Schlossman. 1981. Characterization of a human B cell specific antigen (B2) distinct from B1. J. Immunol. 126: 1941-1947.

25. Ritz, J., L. M. Nadler, A. K. Bhan, J. Notis-McConarty, J. M. Pesando, and S. F. Schlossman. 1981. Expression of common acute lymphoblastic leukemia antigen (CALLA) by lymphomas of $B$ cell and $T$ cell lineage. Blood. 58: 648-652.

26. Reinherz, E. L., P. C. Kung, G. Goldstein, R. H. Levey, and S. F. Schlossman. 1980. Discrete stages of human intrathymic differentiation: analysis of normal thymocytes and leukemic lymphoblasts of $\mathrm{T}$ lineage. Proc. Natl. Acad. Sci. U. S. A. 77: 1588-1592.

27. Reinherz, E. L., and S. F. Schlossman. 1980. The differentiation and function of human T lymphocytes. Cell. 19: 821-827.

28. Nadler, L. M., P. Stashenko, R. Hardy, and S. F. Schlossman. 1980. A monoclonal antibody defining a lymphoma associated antigen in man. J. Immunol. 125: 570-577.

29. Nagasawa, K., and T. W. Mak. 1980. Phorbol esters induce differentiation in human malignant $T$ lymphoblasts. Proc. Natl. Acad. Sci. U. S. A. 77: 2964-2968.

30. Todd, R. F., J. D. Griffin, J. Ritz, L. M. Nadler, T. Abrams, and S. F. Schlossman. 1981. Expression of normal monocyte macrophage differentiation antigens on HL-60 promyelocytes undergoing differentiation induced by leukocyte conditioned medium or phorbol diester. Leuk. Res. 5: 491-495.

31. Bhan, A. K., L. M. Nadler, P. Stashenko, and S. F. Schlossman. 1981. Stages of B cell differentiation in human lymphoid tissues. J. Exp. Med. 154: 737-749.

32. Salmon, S. E., and M. Seligmann. 1974. B cell neoplasia in man. Lancet. I: 1230-1233.

33. Koeffler, H. P., M. Bar-Eli, and M. Territo. 1980. Phorbol diester-induced macrophage differentiation of leukemic blasts from patients with human myelogenous leukemia. J. Clin. Invest. 66: 1101-1108.

34. Totterman, T. H., K. Nilsson, and C. Sundstrom. 1980. Phorbol ester-induced differentiation of chronic lymphocytic leukaemia cells. Nature (Lond.). 288: 176-178.

35. Rovera, G., T. G. O'Brien, and C. Diamond. 1979. Induction of differentiation in human promyelocytic leukemia cells by tumor promoters. Science (Wash. D. C.). 204: 868-870.

36. Huberman, E., and M. F. Callahan. 1979. Induction of terminal differentiation in human promyelocytic leukemia cells by tumor promoting agents. Proc. Natl. Acad. Sci. 76: 1293-1297.

37. Baserga, R. 1981. The cell cycle. N. Engl. J. Med. 304: 453-459.

38. Metzgar, R. S., M. J. Borowitz, N. H. Jones, and B. L. Dowell. 1981. Distribution of common acute lymphoblastic leukemia antigen in nonhematopoietic tissues. $J$. Exp. Med. 154: 1249-1254

39. Vogler, L. B., J. L. Preud'homme, M. Seligmann, W. E. Gathing, W. M. Crist, M. D. Cooper, and F. J. Bollum. 1981. Diversity of immunoglobulin expression in leukemic cells resembling B lymphocyte precursors. Nature (Lond.). 290: 339-341.

40. Korsmeyer, S. J., P. A. Hieter, J. V. Ravetch. D. G. Poplack, P. Leder, and T. A. Waldmann. 1981. Patterns of immunoglobulin gene arrangement in human lymphocytic leukemias. In Leukemic Markers. W. Knapp, editor. Academic Press, Inc., New York. 85-98. 